JOURNAL OF SECURITY AND SUSTAINABILITY ISSUES

ISSN 2029-7017 print/ISSN 2029-7025 online

2019 March Volume 8 Number 3

http://doi.org/10.9770/jssi.2019.8.3(6)

Scopus

\title{
THE MODERATING ROLE OF ENVIRONMENTAL DISASTER IN RELATION TO MICROFINANCE'S NON-FINANCIAL SERVICES AND WOMEN'S MICRO-ENTERPRISE SUSTAINABILITY
}

\author{
Adnan ul Haque', Sebastian Kot ${ }^{2}$, Muhammad Imran ${ }^{3}$ \\ ${ }^{1}$ University of Wales Trinity Saint David - London Campus, Winchester House, \\ 11 Cranmer Road, SW9 6EJ, London, United Kingdom \\ ${ }^{2}$ The Management Faculty, Czestochowa University of Technology, Armii Krajowej 19B, 42-201 Częstochowa, Poland \\ Faculty of Economic and Management Sciences, North-West University, \\ Vaal Triangle Campus, P.O. Box 1174, Vanderbijlpark 1900, South Africa \\ ${ }^{3}$ Faculty of Business Administration, Iqra University Karachi, Pakistan
}

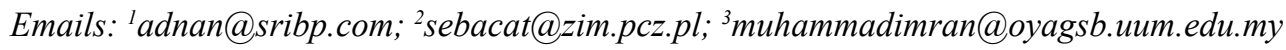

Received 17 March 2018; accepted 20 January 2019; published 30 March 2019

\begin{abstract}
This comparative study explores the contribution of non-financial services, namely, micro training and social capital towards women micro enterprise sustainability in Pakistan and Malaysia, specifically focusing on women, the vulnerable section of the society. Because of gender discrimination, women micro enterprise sustainability is relatively low, and thus, has lower contribution to economy in Pakistan and Malaysia (20\% to 25\%). The moderating role of environmental disaster is considered in this cross-sectional research. The responses were gathered from females working micro enterprises through survey questionnaire while data was analyzed through SmartPLS 3. Results revealed that environmental disaster has significant impact on women micro enterprise sustainability in Pakistan and Malaysia. Micro training also is evident to have statistically significant impact on women micro enterprise sustainability in both countries. Interestingly, social capital has significant impact on women enterprise sustainability in Malaysia while non-significant in Pakistan. Lastly, environmental disaster has significant moderating role between micro training and women micro enterprise sustainability in Pakistan and Malaysia. This study is a pioneer to investigate women micro enterprise sustainability in cross-cultural manner while including environmental disaster's moderating role. Thus, this study assists the governments of Pakistan and Malaysia along with the practitioners to enhance understanding and implement strategies to boost women micro enterprise sustainability.
\end{abstract}

Keywords: social capital; micro training; women micro-enterprise sustainability; environmental disaster; comparative analysis

Reference to this paper should be made as follows: Haque, A. U.; Kot, S.; Imran, M. 2019. The moderating role of environmental disaster in relation to microfinance's non-financial services and women's micro-enterprise sustainability, Journal of Security and Sustainability Issues 8(3): 355-373. http://doi.org/10.9770/jssi.2019.8.3(6)

JEL Classifications: J16; B55; G21

\section{Introduction}

There is no doubt that environmental disasters would impact the wide range of companies and societies. Alas, scale and strength of this impact remains unclear, especially when we consider the most vulnerable targets, such as micro enterprises, women, especially, poor segment (e.g. Njaramba et al. 2018a; 2018b; Belas et al. 2018). Hence, women enterprise sustainability is a major theme behind underpinning this quantitative study. The concept derives from empowerment approach that identifies values and individual's resourcefulness to meet their needs (Harley et al. 2018). This study intakes women enterprise sustainability from the context of self-sustainability, which reflects their individual ability for catering their needs through independent efforts. According to Hameed, Mohammad and Shahar (2018a), in poor community, often higher self-sustainability is 
evident among individuals for survival. Moving in the same vein for explaining the women micro enterprise sustainability, the notion of self-sustainability is explained from vast literature, which view it as "self-sufficiency" (Becker, Kovach, \& Gronseth, 2004; Postmus, 2013; Scott, London \& Gross, 2007), "self-efficacy" (Campione, Morgan \& Jerrell, 2004; Dickerson \& Taylor, 2000) and "financial independence" for fulfilling one's financial needs (Yunus \& Jolis, 2003). Nevertheless, these different terminologies reflect the ability of the individual by carrying out work-related activities by his/her own so that desired financial gains are attained while decision making is independent. The self-sustainability of women through micro enterprises is examined in this study by focusing on non-financial services perspective.

Financial services perspective related to micro enterprises has been explored to larger extent while little evidence available regarding non-financial services to examine women micro enterprises sustainability (Akanji, 2006; Meyer, 2018). Interestingly, the previous empirical studies are largely focused on specific economy, especially developed economy whilst there is no conclusive evidence to examine the relationship between research variables from cross-cultural comparative aspect. In other words, this study delimits the literature of region-specific knowledge by offering cross-cultural perspective to gain wider generalizability. Hence, in this regards, Pakistan and Malaysia are considered cases, because both have large similarities such as, the role of women entrepreneurial activities is largely limited in the male dominated society (Mahmood, 2011; Musa et al. 2016). Additionally, comparison through Hofstede model reflect that masculinity is equal in both Pakistan and Malaysia while longterm orientation and individualism is closely matched (Hofstede, 2018). The work of Kabeer (2012) showed that $70 \%$ women are most vulnerable community in the world, hence, the sustainability is also lower in them in contrast to males. In Malaysia, only $0.8 \%$ reduction in 49.3\% poverty is evident since 1975 (Islam et al. 2017). On the other hand, $40 \%$ of the women in Pakistan are living in poverty while $30 \%$ of them are deprived of social and economic support (Rehman, Moazzam \& Ansari, 2015). Hence, both countries have higher level of poverty, reflecting lower level of self-sustainability in Pakistan and Malaysia. Number of reasons have been identified as cause behind low level of women's self-sustainability in Malaysia and Pakistan however, the most prominent remains "gender discrimination issues" (Faizan \& Haque, 2016; Yasmeen, 2015) by treating and promoting men more in comparison to women in different fields and aspects of life such as, education, sports, etc.

The contribution of women towards gross domestic products (GDP) is lower in comparison to developed economies. For instance, in the United States, women's contribution is approximately $50 \%$ while in Malaysia it is accounted to $34-40 \%$ while in Pakistan, it is between 25 to 30\% (Bosma, 2010; Nil, Hamid \& Woon, 2011; Hameed, Mohammad \& Shahar, 2018b). Thus, this indicates that lower empowered women in Pakistan and Malaysia is due to lower level of self-sustainability in comparison to the US. Due to this, lack of training opportunities and social capital is relatively lower for these women managed enterprises (Kithae, Niyaga \& Kimani, 2013; Kot et al., 2016). In other words, the approach for microfinance institutions to improve is lower, which also indicate that the role of these microfinance institutions is relatively lower in improving the social conditions. The primary goal of microfinance institutes is to reduce the poverty level and to empower their beneficiaries through numerous services such as access to credit facilities, savings, training, insurance, and social network (Al-Shami et al. 2016). Mayoux (2005) argued that through facilitating women's microenterprises, the self-sustainability of women enhances through microfinance institutions. The level of income increases through micro-enterprises and reduce the issues of gender discrimination to some extent (Mayoux, 2005). Hence, micro-enterprises play vital role in improving women's self-sustainability.

Nevertheless, an environmental disaster is another vital factor that affect women's self-sustainability in adverse manner (Blaikie et al. 2004). "It includes different vulnerability factors which determine the degree to which someone's life and livelihood are put at risk by a discrete and identifiable event in nature. These environmental disasters include flood, heavy rainfall, shortage of water and any other environmental factors, etc" (Blaikie et al. 2004; p. 12). Thus, all the aforementioned factors affect the relationship between the non-financial services offered by microfinance institutions (training, and social capital) and women's self-sustainability. Although, other financial services are also affected by environmental disasters, but the focus of this study is on nonfinancial services, therefore, only training and social capital are considered. The constructive contribution of micro-finance institutions towards women enterprise sustainability is limited due to these environmental 
disasters. Hence, environmental disasters are taken as moderating variable to assess the contribution of nonfinancial services towards women-owned and run micro-enterprises.

This study's prime objective is to investigate the role of non-financial services of microfinance institutions in relation to women's self-sustainability in comparative manner by examining in Malaysia and Pakistan. Following are the two sub-objectives:

1. To investigate the role of microfinance institution's non-financial services (micro training and social capital) in the success rate of women's micro-enterprises.

2. To investigate the moderating role of environmental disaster between a microfinance institution's nonfinancial services (micro training and social capital) and the success of women's micro-enterprise (Figure 1).

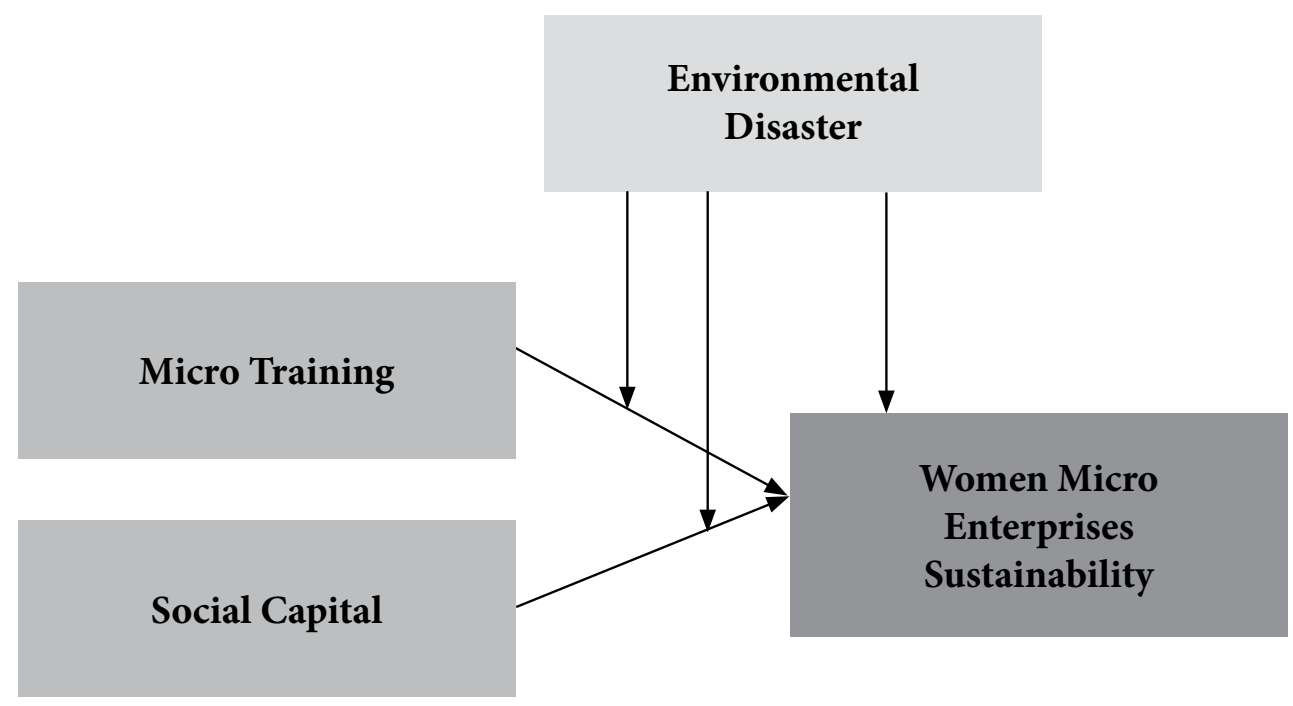

Figure 1. Current research theoretical framework representing the micro finance non-financial services in relation to women micro enterprise sustainability with environmental disaster as moderating variable.

This is pioneer in expanding the knowledge through focusing on non-financial services of micro finance institutions as a major facilitator of women's micro enterprise sustainability. Previous studies are available regarding the relationship between microfinance and women empowerment or higher emphasise on the financial services of micro finance institutions. Nevertheless, at hand literature has not explored the non-financial services of microfinance institutions affecting women self-sustainability through micro enterprises. Additionally, the major contribution of this research is use of environmental disasters (i.e. moderator) as a limiting factor (especially in developing countries like Malaysia and Pakistan) regarding the constructive contribution of microfinance institutions' non-financial services towards women's self-sustainability. Previous research studies have not formally documented environmental disasters as a threat towards women micro enterprise' sustainability. Prior studies have had recommended environmental disaster as moderator for future studies (Gaiha \& Thapa, 2006; Hameed et al. 2018a; Harley et al. 2018). Therefore, this study builds on it by considering it as a moderator. In addition to that, this study undertakes comparative approach to examine the relationship between research variables by considering two similar alike emerging economies to have wider generalizability. Furthermore, the Pakistan Microfinance (PMR) Report (2017) revealed that negative environmental factors are destroying the women's micro enterprises, reflecting limited positive contribution of microfinance institutions. Hence, indicating that women's low self-sustainability is due to these environmental factors. The study expands on highlighting the limitation of the Mayoux's Feminist Empowerment Theory as it is not applicable in all environments. According to this theory, microfinance services enhance women advancement (Mayoux, 2005). While, the earlier report showed that microfinance services are not beneficial. However, the report largely considered financial services while there is a need to assess the theory through non-financial services, which is the contribution towards knowledge in the area. Moreover, the governments of considered economies would benefit as the policy makers could use the suggestions to improve the non-financial services of microfinance institutions in improving the women's self-sustainability. 


\section{Literature Review}

\subsection{The Underpinning Theories}

\subsubsection{Mayoux's Feminist Empowerment Theory:}

In the context of microfinance, women empowerment serves a base for the women's self-sustainability (Harley et al.2018). In the same vein, the women empowerment issue is addressed through Mayoux's feminist empowerment theory to a large extent (Mayoux, 1999). Since, Pakistan as well as Malaysia are emerging economies thus, this theory is based on the degree of attention emerging countries have paid to women empowerment from a lens of social and economic viewpoint. Nevertheless, this theory's ultimate objective is creation of self-sustainability among women. Gender discrimination in terms of jobs, wealth and income are the common issues faced by women in various parts of the emerging world (Mayoux, 2005). Additionally, the intrusion on their basic human rights such as access to nutrition, respect, health care, education and independence in decision-making (Mayoux, 2005). According to this theory, "women empowerment can be achieved by providing access to credit facilities through microfinance institutions" (Mayoux, 2005). Both, financial capital assistance and nonfinancial services such as micro training and social capital could be pivotal in attaining women empowerment, which is generating income related activities in micro-enterprises (Mayoux, 2005). Nevertheless, skills and social capital are lacking in emerging economies like Pakistan and Malaysia (IBRU, 2009). "Moreover, microinsurance policies cover the loss in micro-enterprises if any, in the event of the occurrence of natural disasters or any other vulnerability factor" (Mayoux, 2005).

Poverty alleviation, financial self-sustainability and feminist empowerment are three core paradigms of Feminist empowerment theory, as shown in Figure 2 (Mayoux, 1998). Incorporating microfinance for empowering women, all the considered aspects in paradigm are formed. Theory offers a methodical structure for empowering women through microfinance services such as micro-credit, micro-saving, micro-insurance and any other financial as well as non-financial services. However, in this study, only non-financial services are considered to examine the impact on the women's micro enterprise sustainability.

This theory provides a link between microfinance institutions and women's self-sustainability thus reducing their poverty level and gender discrimination against them. It enhances the success of women-owned and run micro-enterprises through various services offered by microfinance institutions (micro training and social capital). 


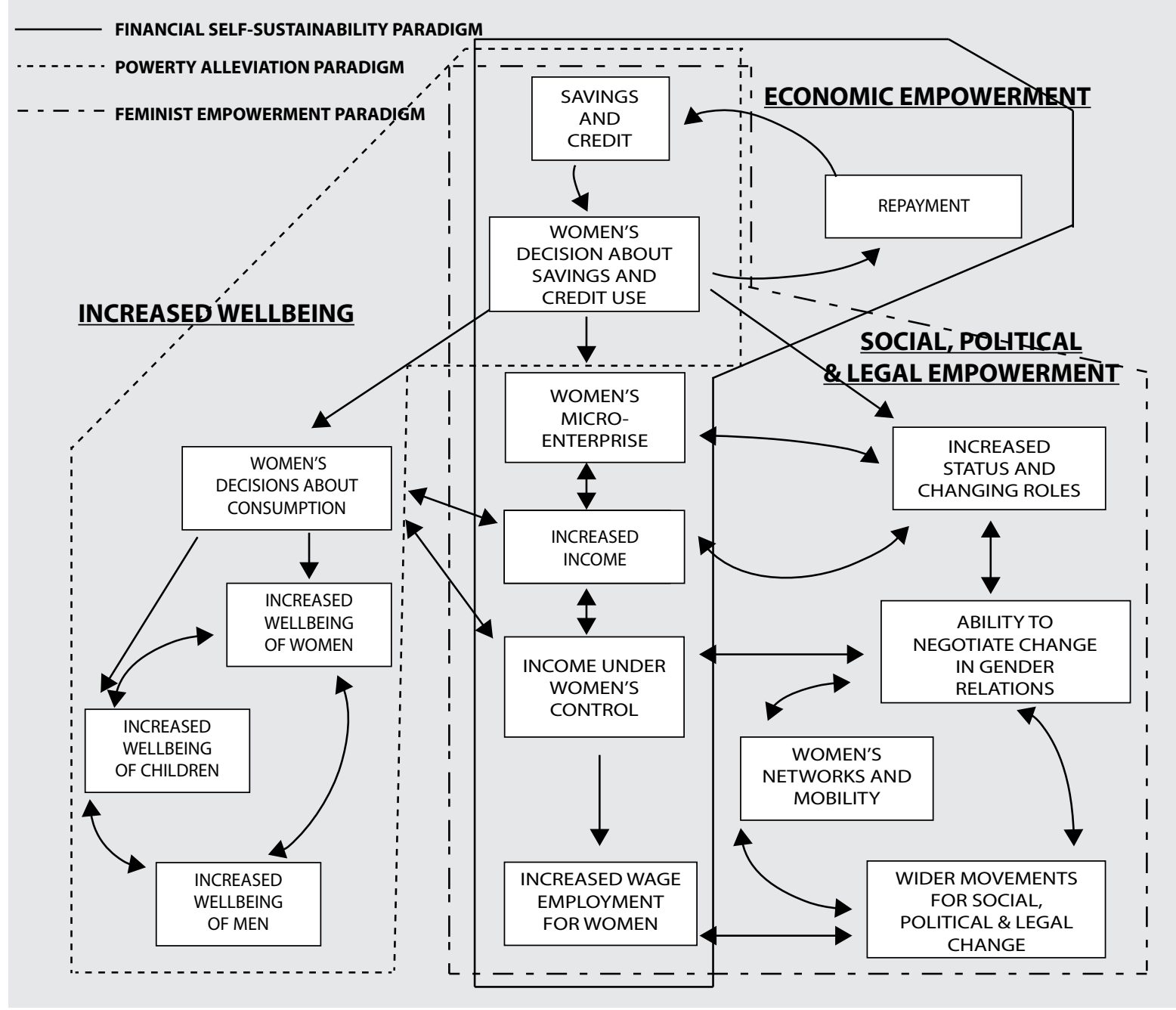

Figure 2. Mayoux's Feminist Empowerment Theory: A framework linking the women advancement with various microfinance institutions services (Mayoux, 2005)

Above figure reflects that women self-sustainability is a resultant of the microfinance institutions' services. The decision-making power enhance due to accessibility towards facilities and credit attainment (Figure 2). Due to accessibility to facilities, women by their own decide the procedure and time for repaying loans. Additionally, the economic and social status improve as well as the income generate further due to investment in microenterprises. Hence, income flow under women's own control and therefore, they develop the ways to decrease gender discrimination in the emerging economies. The microfinance process assists women in the development of free social network that eventually increases the employment rate among women as well as improve their social, legal and political outlook.

\subsection{A Relational Theory of Risk}

Bohlom \& Corvellec (2011) explained that "an object at risk, a risk object and a relationship of risk are three main components of a relational theory of risk" that is undertaken in this study to explain the environmental disaster perspective. "An object at risk is an object having some value which is at stake. However, a risk object is any entity which threatens the object at risk. Finally, the relationship of the object at risk and a risk object is called a relationship of risk" (Bohlom \& Corvellec, 2011). The equation of theory is given below: 
"Risk objects are similar to hazards in the sense that it denotes something that is acknowledged as dangerous" (Bohlom \& Corvellec, 2011), that includes, environmental factors such as heavy rainfall, shortage of water, flood and any other environmental disaster. "Environmental vulnerability also consists of hazards such as natural calamities, climate changes and any other environmental negatives" (Birkmann, 2006; McEntire et al. 2010). Therefore, a risk object in this study is an environmental disaster. "An object at risk is based on the object having some value which is at stake due to the presence of a risk object (i.e. it is prone to risk)" (Bohlom \& Corvellec, 2011). Bourdieu (2003) explained that, "in modern societies, value is referred to as worth, life, nature, principles and so on by considering it in monetary terms". Hence, economic and social status is both considered as an object at risk. Additionally, success of women's micro-enterprises is object at risk. In other words, environmental disasters (risk object) may harm the success of women's micro-enterprises sustainability (object at risk).

Finally, "the relationship of risk implies to the association that an observer establishes between the object at risk and the risk object. This relationship is a causal relationship in which a risk object may modify the object at risk" (Bohlom \& Corvellec, 2011). According to Bohlom \& Corvellec (2011), the linkage must form in a manner that the risk object threatening the object at risk should be investigated in terms of how and why it happens. In this research, the causal relationship between environmental disaster and the success or otherwise of women's micro-enterprise is exerted. In addition to that, an invaluable relationship exist between the nonfinancial services offered by microfinance institutions and the success of women's micro-enterprises their selfsustainability. In this regard, this invaluable relationship is also treated as an "object at risk," and environmental disaster (a risk object) may limit (modify) this relationship. Therefore, in this study, an environmental disaster is treated as a "risk object". The success of women's micro-enterprises and its sustainability is treated as an "object at risk".

In present context, the aforementioned theory's equation is stated below:

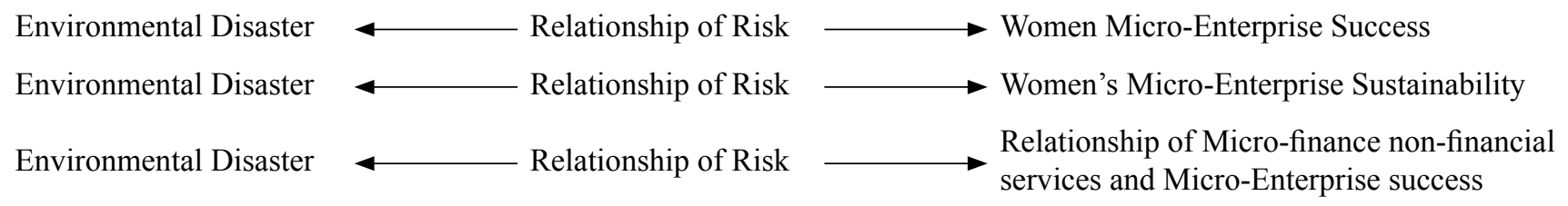

Empowerment is a key for women's self-sustainability in micro-enterprises. According to Stromquist (2015), nongovernment organizations (NGOs) and micro-finance institutions are vital for empowering women, especially in emerging economies. Distinctive types of skills and knowledge reflects empowerment (Stromquist, 2015). Women is enabled through women empowerment to become economically independent, positive self-esteem and self-reliance that allows them to overcome social and economic challenges while participate in various developmental activities (Kapila, Singla \& Gupta, 2016). Hence, it indicates that nation's economy boosts to certain extent due to escalated women self-sustainability. On the other hand, rapid growth is evident among the micro-finance in the world (Burżacka \& Gąsiorowska, 2016; Dichter, 2007; Garikipati, 2008), where risk and venture capital financing are evident (Burżacka \& Gąsiorowska, 2016). Interestingly, approximately in 60 countries, microfinance is operating effectively (Bateman, 2010). Professor Muhammad Younus set micro-finance institution in Bangladesh that led to the concept of self-employment through micro-enterprises, which advanced the economic empowerment, improved living standards, prosperity and skill development (Bateman, 2010).

In Malaysia, the microfinance institution is Amanah Ikhtiar Malaysia (AIM) while Agha Khan Rural Support Program (AKRSP) and Orangi Pilot Project (OPP) in Pakistan, which offers microfinance services (Hameed, Imran, Śusarczyk \& Haque, 2019; Pokhriyal, Rani \& Uniyal, 2014). Afterward, many other microfinance institutions began to provide various microfinance services. These institutions have been significant in selfsustainability development through the provision of various services such as credit, saving, insurance, training, social capital, and entrepreneurial education. In this study, non-financial microfinance services include micro training and social capital. 
Akanji (2006) explained microfinance institutions offer micro training, which is vital service to improve expertise and skills of women entrepreneurs. The businesses face serious challenge that lack expertise and skills. Micro credit and micro savings consider micro training equally important (Akanji, 2006). Although, financial resources' adequate utilization is key for the success of micro-enterprise, but the results rely on micro training. The success of micro-enterprise is negatively affected in the absence of micro training (Nsengimana, Tengeh \& Iwu, 2017). The adequate training is required for the women entrepreneurs to be significant in contributing towards country's economic growth (Meyer, 2018; Ślusarczyk \& Broniszewska, 2014). The well-being, level of income and self-sustainability are significantly influenced by micro training and microenterprises, which also is pivotal for the improvement of success of women owned firms (Sulphey \& Alkahtani, 2016). Micro-enterprises are positively influenced by micro training (Cheston \& Kuhn, 2002). Whilst above discussion revealed that the success rate of women's micro-enterprises relies on micro training. However, there is no evidence from the distinctive emerging economies about this relationship. Therefore, the null hypothesis is as following:

H1: Micro training has no statistically significant impact on the women's micro-enterprise sustainability in distinctive emerging economies.

Another microfinance institution's non-financial service is social capital that is linked to the formation of network of people. "Social capital is defined as 'the connections among individuals - social networks and the norms of reciprocity and trustworthiness that arise from them" (Putnam, 2000). Individuals or groups are given the services by microfinance institutions in order to improve their social connections while self-help group (SHE) is also the way of improving the social outlook, offered by microfinance institutions. This networking proves efficient in improving the chances of individuals to attained credit while the formed groups also support one another in the development (PMR, 2017). "The microfinance institution then provides credit to the group. This activity develops and engenders social capital among SHE groups, which in turn, helps them to run their businesses through shared knowledge and experience" (PMR, 2017). Number of societies have used social capital concept for increasing developmental activities (Wansamo, 2007). A network of individuals serves grounds for social capital formation, which increase sustainable development in society and enhance economic growth (Mafukata, Dhlandhlara \& Kancheya, 2015). "In a strong network of relations, people support each other to expedite income generating activities like micro-enterprises. An SHE group is one of the ways of raising initial capital for business because members support and spur each other" (Wansamo, 2007). Hence, SHE group tends to enhance the success rate of women's micro-enterprises and their sustainability. Mafukata et al. (2015) argued that the individual as well as collective group tasks are effectively accomplished by the collaboration and active participation in the developed network. The success and stability of women' micro-enterprise is due to social relations. Nevertheless, there are no evidence regarding the relationship from distinctive emerging economies. Thus, proposed null hypothesis is as following:

H2: Social capital has no statistically significant impact on the women's micro-enterprise sustainability in distinctive emerging economies.

Nevertheless, existing literature at hand revealed that there are mixed views as few supports while other contradicts the benefits of non-financial microfinance institutions in regard to women micro-enterprise sustainability. According to Harley et al. (2018) it is likely that microfinance services might produce positive results and accomplish strategic objectives, but all types of services would always bring desired results. The discussions above also revealed that to larger extent, the positive significant impact of microfinance institutions on women's self-sustainability and their micro-enterprises' sustainability. However, only fewer studies attained to the conclusion of either a no/less/negative impact of microfinance in this regard. Number of studies viewed lack of financial capital as a reason for negative effect of microfinance on success rate of women's microenterprises (Atmadja, Su \& Sharma, 2016). Nevertheless, studies also revealed that lack of social capital and training adversely affect the women's micro-enterprises rate of success (Buckley, 1997; Mosley \& Hulme, 2009). The inconsistency in findings could be resolved through introduction of moderating variable. "A moderator is a variable which affects the strength of the relationship between independent and dependent variables" (Baron \& Kenny, 1986). Hence, moderating variable is used in this study to resolve earlier studies' inconsistency. Environmental disaster is moderating variable undertaken in this study to assess the relation 
between microfinance institution's non-financial services (i.e. micro training and social capital) and the success of women's micro-enterprises. It was suggested by previous studies (Banerjee \& Jackson, 2017; Hameed et al. 2018a). These previous works had proposed that economic, environmental, political and social vulnerability should be considered as moderators to assess the relationship between microfinance services and womenowned and run micro enterprises. Environmental disasters include windstorms, water shortage, heavy rains, floods and so on that affects adversely and disturb the operations of women's micro-enterprise sustainability. Often, individuals use their savings and credits to recover from disasters, which they perhaps borrow from other in shape loan and need to repay in case they have no sufficient savings. Hence, welfare of people declines due to natural disasters (Banerjee \& Jackson, 2017) and it affects women's self-sustainability directly as well as indirectly through the success rate or otherwise of women's micro-enterprise. Hence, null hypotheses are proposed as following:

H3: Environmental disaster does not have a statistically significant imapct on the women's micro-enterprise sustainability in distinctive emerging economies.

H4: Environmental disaster does not moderate the relationship between the micro training and women's microenterprise sustainability in distinctive emerging economies.

H5: Environmental disaster does not moderate the relationship between the social capital and women's microenterprise sustainability in distinctive emerging economies.

\section{Research Methodology}

In this study, cross-sectional research design is used while quantitative methods are employed to statistically attain the research objectives via hypothetico-deductive approach. The survey questionnaire was formed through literature at hand and circulated manually to female clients of microfinance institutions in Pakistan and Malaysia but were limited to only clients who had direct involvement in micro-enterprises by using the services offered by microfinance institutions. The 5-point Likert scale was used for second section's questions (1=Strongly Disagree, 2=Disagree, 3=Neutral, 4=Agree, and 5=Strongly Agree). Comrey \& Lee's (1992) statistical formula was used to determine sample size. As per the series of Comrey \& Lee (1992), over 200 sample size is satisfactory while 300 is good enough for drawing conclusion. Thus, in this research over 300 was targeted. The sample size is 304 (152 each in Pakistan and Malaysia), which is a good sample size for drawing conclusion. In this study, area cluster sampling technique was used as there was no sampling framework, and this technique does not require sampling framework (Comrey \& Lee, 1992). Additionally, this technique is effective reaching large number of respondents in geographic manner. Considering Pakistan and Malaysia as two densely populated regions, this technique is more feasible and appropriate to reach women using microfinance services. The first step in this sampling technique was categorizing population in terms of states. Pakistan has five states while Malaysia had 13 states respectively. Three from Pakistan while 7 from Malaysia was randomly selected so that at least over $50 \%$ in terms of total states are considered. The equation for each cluster was based on $[\mathrm{nz}=(\mathrm{Nz} / \mathrm{N}) * \mathrm{n}]$.

Note: $\mathrm{nz}=$ required sample size for each cluster, $\mathrm{Nz}=$ total population of each cluster, $\mathrm{N}=$ total population size in all clusters, $\mathrm{n}=$ total sample size

The Head office of Pakistan Microfinance Review in Pakistan while Amanah Ikthiar Malaysia (AIM), Yayasan Usaha Maju (YUM) and The Economic Fund for National Entrepreneus Group (TEKUN) in Malaysia were requested for females in each considered cluster. The total number of female clients in selected clusters was approximately over 3.1 million in both countries. The split of three states in Pakistan and seven states in Malaysia, which was randomly done was further explored by finding the female clients in these regions. However, the total population of these selected clusters is 3 million $(15.5+1.60)$. Now, the sample size for each cluster was calculated as follows; 
Hence, 500 survey questionnaires were distributed in each country while ensuring that equal splits are maintained. Total 304 (152 in each country) completed questionnaires were received, reflecting 30.4\% response rate. These 152 were the females who had availed microfinance services, especially social capital and micro training in managing their micro-enterprises. therefore, in the sample of the current study, only women who have enjoyed all these microfinance institutions services were selected.

Table 1. Response from respondents

\begin{tabular}{|l|c|}
\hline \multicolumn{1}{|c|}{ Response } & Frequency/Rate \\
\hline Total questionnaires distributed & 1,000 \\
\hline Total questionnaires returned & 367 \\
\hline Total Useable questionnaires & 304 \\
\hline Total questionnaires excluded & 63 \\
\hline Total response rate & $36.70 \%$ \\
\hline Total response rate of the usable questionnaire & $30.40 \%$ \\
\hline
\end{tabular}

Naala's (2016) measures were adapted for social capital, while micro training constructs were taken from Bernard, Kevin \& Khin (2016). Harley et al. (2018) measures were considered for self-sustainability of women through micro enterprises and the study of Mata-Lima et al. (2013) was used to construct the environmental disasters impact on research variables. SmartPLS structural equation modeling (SEM) is used for quantitative analysis. The validity and reliability of the instruments were checked through statistical tests. The ethical considerations were maintained during the entire research by keeping no disclosure of personal information of respondents to anyone.

\section{Results and Analysis}

Overall, majority of the females participated in this study from Pakistan lies in the age bracket between (35-44) (34\%) while from Malaysia 38\% between (45-54) age bracket. In Pakistan, majority having bachelor's degree $(28.2 \%)$ while in Malaysia majority have master's (31.2\%). In Pakistan, majority have the experience of 5-8 years (36\%) while in Malaysia $40.2 \%$ have experience of over 10 years.

\section{Measurement Model Validation}

The assessment of measurement model is analysed through Smart-PLS 3.2.7 (Ringle et al. 2015). In order to conclude validation of measurement model, reliability, convergent and discriminant validity are examined. In both countries, the reliability of individual items is examined through factor loading, which are greater than 0.70 threshold value. The Cronbach alpha $(\alpha)$, composite reliability (CR), and average variance extracted (AVE) are found acceptable as $\alpha \leq 0.70, \mathrm{CR} \leq 0.70$ and AVE $\leq 0.50$ for each construct in both economies (Table 2). Thus, this fulfil the criterion of Hair, Hult, Ringle \& Sarstedt (2014), reflecting the measurement model is valid and acceptable.

Table 2: Finding of the measurement model (first order, reflective)

\begin{tabular}{lcccccc}
\hline \multicolumn{1}{c}{ Constructs } & \multicolumn{3}{c}{ Pakistan } & \multicolumn{3}{c}{ Malaysia } \\
\cline { 2 - 7 } & A & CR & AVE & A & CR & AVE \\
\hline Environmental Disaster & 0.809 & 0.874 & 0.635 & 0.795 & 0.866 & 0.619 \\
Micro Training & 0.794 & 0.879 & 0.708 & 0.774 & 0.869 & 0.689 \\
Social Capital & 0.783 & 0.871 & 0.692 & 0.769 & 0.863 & 0.678 \\
Women Micro Enterprise Sustainability & 0.761 & 0.848 & 0.582 & 0.76 & 0.847 & 0.581 \\
\hline
\end{tabular}


The model external consistency is considered to determine discriminant validity through Fornell-Larcker's criterion and cross loading. As per Fornell \& Larcker (1981), latent variables'AVE greater than the square root average variance extracted, indicate valid results. Below the results in both countries are evident to be greater than 0.50, reflecting that all constructs have external validity (Table 3).

Table 3: Discriminant Validity (Fornell-Larcker criterion)

\begin{tabular}{|c|c|c|c|c|}
\hline Constructs & $\begin{array}{l}\text { Environmental } \\
\text { Disaster }\end{array}$ & Micro Training & Social Capital & $\begin{array}{c}\text { Women Micro Enterprise } \\
\text { Sustainability }\end{array}$ \\
\hline \multicolumn{5}{|c|}{ Pakistan } \\
\hline Environmental Disaster & 0.797 & & & \\
\hline Micro Training & 0.719 & 0.842 & & \\
\hline Social Capital & 0.552 & 0.581 & 0.832 & \\
\hline Women Micro Enterprise Sustainability & 0.779 & 0.781 & 0.582 & 0.763 \\
\hline \multicolumn{5}{|c|}{ Malaysia } \\
\hline Environmental Disaster & 0.787 & & & \\
\hline Micro Training & 0.728 & 0.83 & & \\
\hline Social Capital & 0.552 & 0.607 & 0.823 & \\
\hline Women Micro Enterprise Sustainability & 0.777 & 0.776 & 0.583 & 0.762 \\
\hline
\end{tabular}

According to Henseler, Ringle \& Sinkovics (2009), the criterion for assessing the external validity is to examine the obtained value less than 1 , hence, lower the value would indicate higher discriminant validity. Below table revealed that the model has acceptable discriminant validity (Table 4).

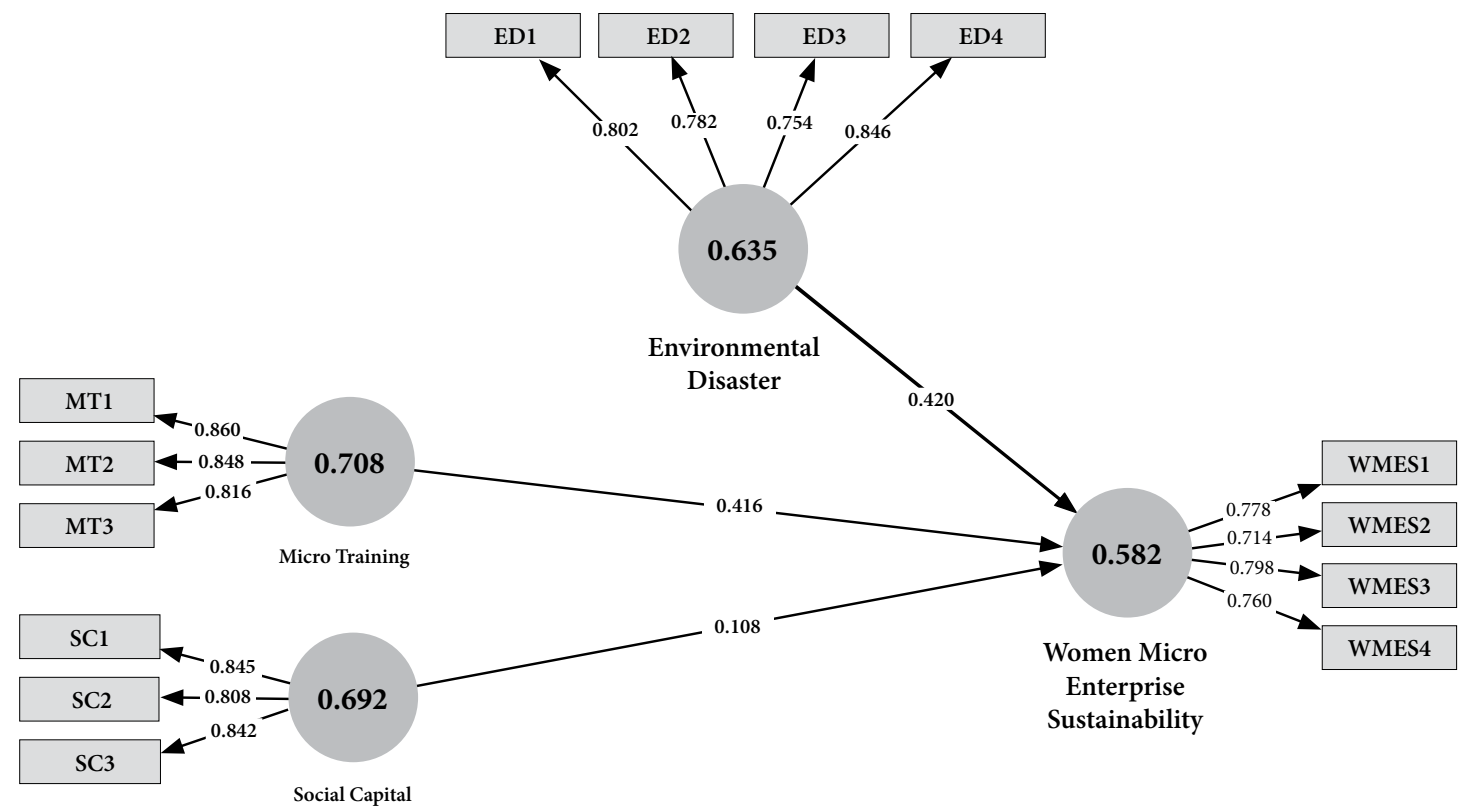

Figure 3: Constructs' discriminant validity in Pakistan 


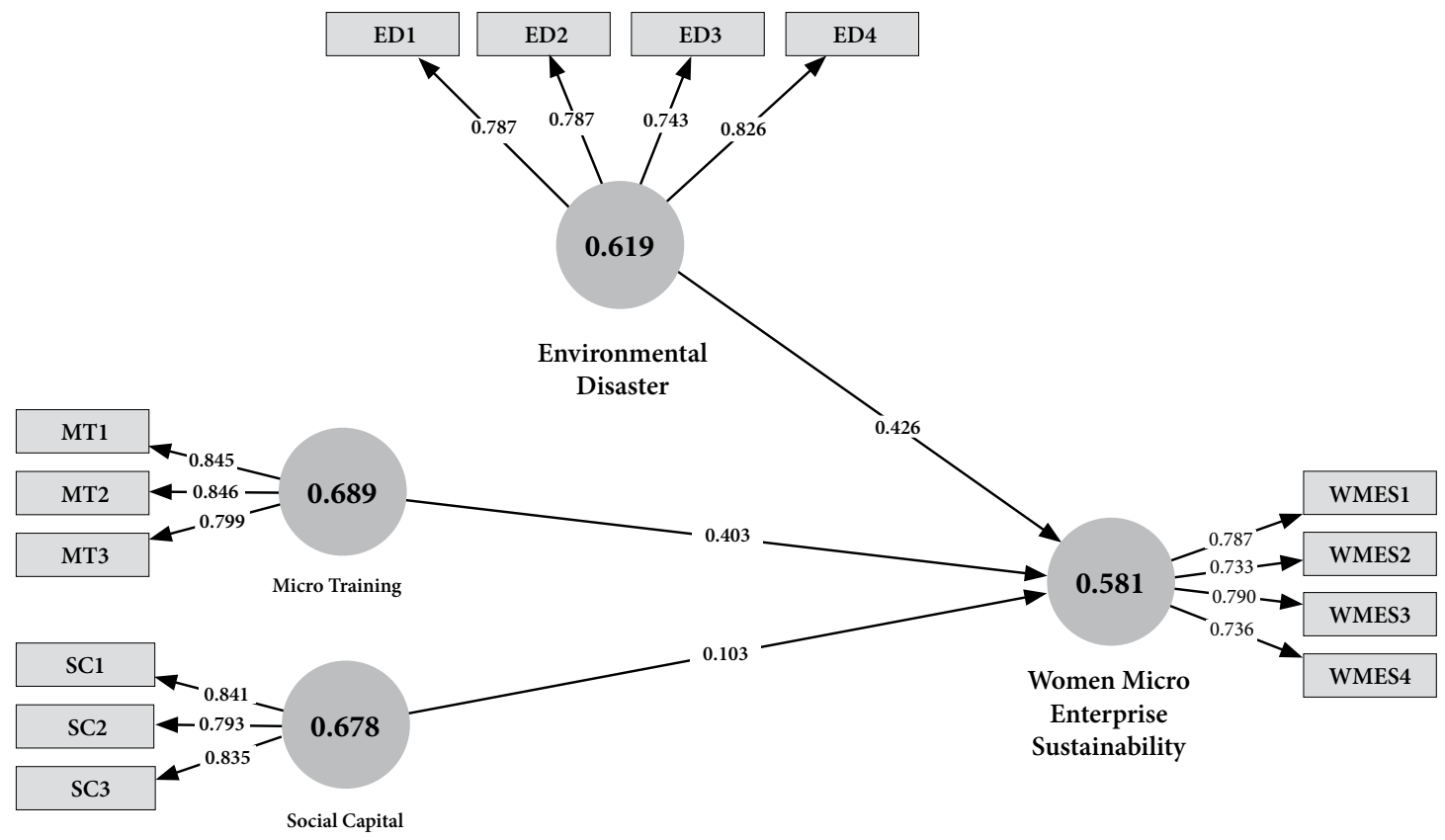

Figure 4: Constructs' discriminant validity in Malaysia

Table 4: Heterotrait-monotrait ratio of correlations (HTMT)

\begin{tabular}{|c|c|c|c|c|}
\hline Constructs & Environmental Disaster & Micro Training & Social Capital & $\begin{array}{l}\text { Women Micro Enterprise } \\
\text { Sustainability }\end{array}$ \\
\hline \multicolumn{5}{|c|}{ Pakistan } \\
\hline \multicolumn{5}{|l|}{ Environmental Disaster } \\
\hline Micro Training & 0.89 & & & \\
\hline Social Capital & 0.672 & 0.717 & & \\
\hline $\begin{array}{l}\text { Women Micro Enterprise } \\
\text { Sustainability }\end{array}$ & 0.969 & 0.995 & 0.726 & \\
\hline \multicolumn{5}{|c|}{ Malaysia } \\
\hline \multicolumn{5}{|l|}{ Environmental Disaster } \\
\hline Micro Training & 0.921 & & & \\
\hline Social Capital & 0.683 & 0.766 & & \\
\hline $\begin{array}{l}\text { Women Micro Enterprise } \\
\text { Sustainability }\end{array}$ & 0.98 & 0.881 & 0.734 & \\
\hline
\end{tabular}

\section{Structural Model Assessment}

Using same SmartPLS 3, structural model was accessed by following the previous studies' recommendations (Hair \& Lukas, 2014; Hair et al. 2012; Henseler et al. 2009). First, the direct relationship between variables are analyzed while later moderator is introduced to assess the relationship between research variables. After examining the impact of micro training and social capital on women's micro-enterprise sustainability, the environmental disaster is included to assess the moderating effect. In addition to that, the size effect $\left(\mathrm{f}^{2}\right)$ and predictive relevance $\left(\mathrm{Q}^{2}\right)$ was examined to measure the size as well model quality. 
Table 5: Findings of structural model

\begin{tabular}{|c|c|c|c|c|c|c|}
\hline Hypothesis & $B$ & SD & T Value & Decision & $f 2$ & $R 2$ \\
\hline \multicolumn{7}{|l|}{$\begin{array}{ll} & \text { Pakistan } \\
\end{array}$} \\
\hline Environmental Disaster -> Women Micro Enterprise Sustainability & 0.412 & 0.074 & 5.539 & 0.000 & 0.279 & 0.713 \\
\hline Micro Training -> Women Micro Enterprise Sustainability & 0.371 & 0.07 & 5.265 & 0.000 & 0.199 & \\
\hline Social Capital -> Women Micro Enterprise Sustainability & 0.088 & 0.058 & 1.514 & 0.130 & 0.017 & \\
\hline Micro training*Environmental Disaster $->$ Women Micro Enterprise Sustainability & 0.087 & 0.038 & 2.273 & 0.023 & & \\
\hline \multicolumn{7}{|l|}{ Malaysia } \\
\hline Environmental Disaster -> Women Micro Enterprise Sustainability & 0.418 & 0.051 & 8.265 & 0.000 & 0.274 & 0.690 \\
\hline Micro Training -> Women Micro Enterprise Sustainability & 0.368 & 0.049 & 7.457 & 0.000 & 0.142 & \\
\hline Social Capital -> Women Micro Enterprise Sustainability & 0.085 & 0.043 & 1.931 & 0.057 & 0.015 & \\
\hline Micro training*Environmental Disaster $->$ Women Micro Enterprise Sustainability & 0.072 & 0.028 & 2.583 & 0.010 & & \\
\hline
\end{tabular}

Note: ${ }^{* * *} p<0.1,{ }^{* *} p<0.05, \mathrm{~ns}=$ nonsignificant $(\mathrm{p}>.05)$ (Two Tail)

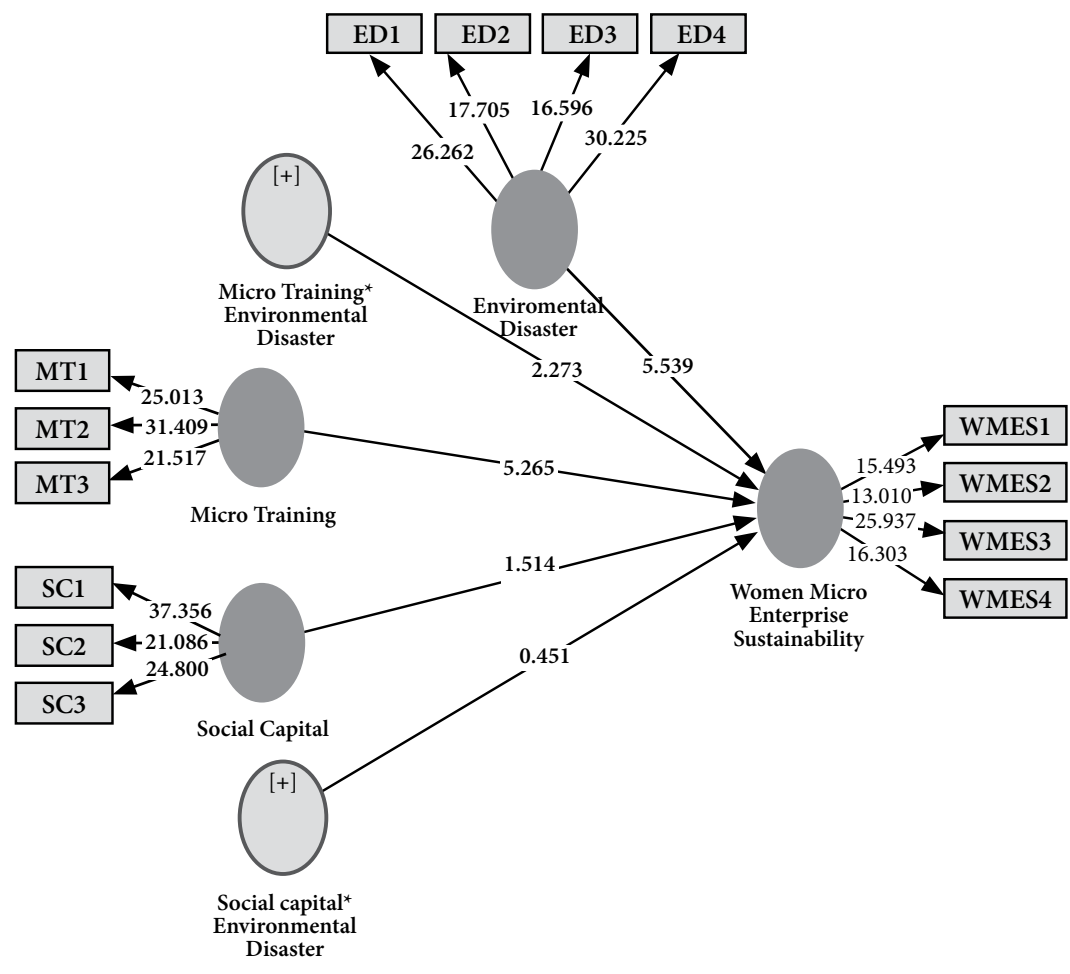

Figure 5: Pakistan 


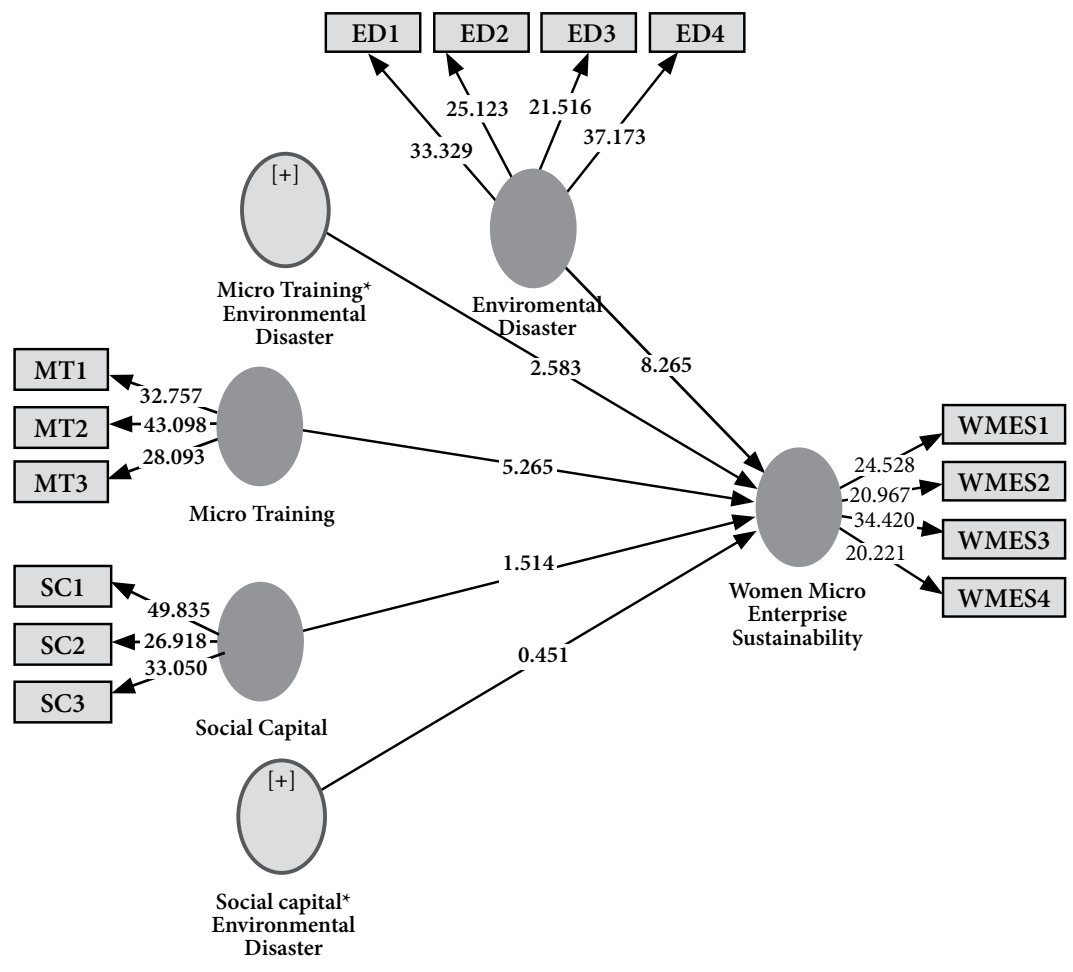

Figure 6: Malaysia

Table 5 contains the results of direct and moderate relationship. Threshold value is t-value, which is 1.96 to determine the significance. Additionally, p-value of 0.05 is also used. The results of direct effect are measured through a t-value of greater than 1.96 and a p-value below 0.05 for not rejecting hypotheses. The predictive accuracy of model is measured through $R^{2}$ by considering 0.25 (weak), 0.50 (moderate), and 0.70 (strong) respectively (Hair et al. 2012). In present study, $\left(R^{2}\right)$ reflects strong variation in Pakistan and Malaysia $(0.713$ and 0.69 ) indicating $71.3 \%$ in Pakistan while $69 \%$ in Malaysia (Table 5).

The results showed that environmental disaster has a statistically significant impact on women's micro-enterprise sustainability in Pakistan $(t$-value $=5.539>1.96 ; p<\alpha=0.000<0.05$; Table 5) and Malaysia $(t$-value $=8.265>$ 1.96; $p<\alpha=0.000<0.05$; Table 5). Thus, there is strong evidence against null hypotheses. In other words, environmental disaster significantly affects women micro-enterprise sustainability in distinctive merging economies. In addition to that, In Pakistan, environmental disaster causes 0.41 variation in micro-enterprise sustainability while 0.46 in Malaysia (Table 5). Moreover, micro training has a statistically significant impact on the women micro-enterprise sustainability in Pakistan $(t$-value $=5.265>1.96 ; p<\alpha=0.000<0.05$; Table 5) as well as in Malaysia ( $t$-value $=7.457>1.96 ; p<\alpha=0.000<0.05$; Table 5). Therefore, in this regard, null hypothesis is not rejected. The variation caused by micro training in women micro-enterprise sustainability is 0.371 in Pakistan while 0.368 in Malaysia Table 5). Interestingly, the statistical test revealed that social capital does not have a significant impact on the women micro-enterprise sustainability in Pakistan ( $t$-value $=1.514<$ 1.96; $p<\alpha=0.130>0.05$; Table 5) and Malaysia ( $t$-value $=1.931<1.96 ; p<\alpha=0.000>0.057$; Table 5). Thus, there is no strong evidence against null hypothesis, as a result, this study fails to reject null hypothesis. Since, social capital is evident to have no statistically significant impact on the women's micro-enterprise sustainability, therefore, the moderating role cannot be assessed. In other words, there is no significant relationship, hence no moderation could be established. The environmental disaster is examined as a moderator between micro training and women's micro-enterprise sustainability and results revealed that environmental disaster significantly moderates the relationship between considered research variables $(t$-value $=2.58>1.96 ; p<\alpha=0.010<0.05$; Table $5)$. There is evidence against null hypothesis, therefore, it is rejected. Furthermore, there is 0.072 moderation caused by environmental disaster between research variables. In other words, environmental disaster moderates the relationship between micro training and women's micro-enterprise sustainability. 
According to Cohen et al. (2013), "the values of $f^{2}$ are considered as small (0.02), medium (0.15) and large (0.35) respectively". In this study, the size effect of micro training $(0.199 ; 0.142)$ as well environmental disaster $(0.279 ; 0.274)$ is moderate in Pakistan and Malaysia while social capital has weak effect in both countries; Pakistan (0.017) and Malaysia (0.015) (Table 5).

\section{Findings and Discussion}

Results of this study showed that non-financial service; 'micro training' has a statistically significant impact on women's micro-enterprise sustainability. Since, the t-value is 5.265 in Pakistan while 7.457 in Malaysia, which are significant and the positive $\beta$-value 0.371 and 0.368 reflecting positive variation caused by micro training (predictor). Hence, micro training increases women self-sustainability through their micro-enterprises. In other words, micro training contributes towards women's self-sustainability through micro-enterprises. Hence, this study contradicts the work of Hameed et al. (2018a) while confirms the previous empirical studies (Akanji, 2006; Cheston \& Kuhn 2002; Sulphey \& Alkahtani, 2016). Moreover, the environmental disaster is evident to have a significant moderate role between micro training and women's micro-enterprise training as t-value is 2.272 in Pakistan and 2.583 in Malaysia while the positive $\beta$-value 0.087 in Pakistan and 0.072 in Malaysia, reflecting positive moderation caused by environmental disaster. The reason for higher variation in Pakistan is due to inconsistent environmental factors such as disaster, water shortage and prevalence of windstorms in Southern regions while flooding and rainy season in Malaysia cause destruction to women owned microenterprises in Malaysia. Hence, the environmental issues create difficult situation regarding the loan repayment as well as attainment of training from microfinance institutions.

On the other hand, sometimes microfinance institutions do not provide the complete package of their services to their clients. For instance, they provide financial capital to women but do not provide human capital such as training to the women on how to run micro-enterprises established with microcredit. As explained by Garikipati (2008) that microfinance through social capital and micro training helps the women empowerment. Thus, to large extent work of Simpson, Tuck \& Bellamy (2004) is indirectly supported that in the absence of training and social capital development opportunities, the business suffers losses. However, this study found no statistically significant relationship between social capital and women's micro-enterprises sustainability because t-value is 1.514 in Pakistan and 1.931 in Malaysia, hence, this study opposes the work of Kithae et al. (2013) and IBRU (2009). Nevertheless, work of Atmajda et al. (2016) is supported considering micro training while opposes same study considering social capital.

Thus, micro training is a strong predictor, but social capital is not significant predictor, and hence micro training is consistent with the Mayoux's feminist empowerment theory (Mayoux, 2005). Whilst inconsistent with same theory of Mayoux (2005) in context of social capital. Asserted theory in the framework of empowerment indicates that microfinance facilitate women's micro-enterprises that leads to women's self-sustainability. This study found a significant positive relationship between the success of women's micro-enterprises sustainability and environmental disaster with t-value 5.539 in Pakistan and 8.265 in Malaysia. Nevertheless, significant positive relationship between microfinance institutions and the success of micro-enterprises, thus, confirms the previous studies (Atmadja et al. 2016; Bernard et al. 2016; Buckley, 1997; Harley et al. 2018; Mosley \& Hulme, 2009).

Previous studies are largely commenced in Africa and Bangladesh (Swain \& Floro, 2014; Hossain, 2007) while examining environmental factor's vulnerability on success of women-owned micro-enterprise. On the other hand, large studies focused on financial services of microfinance institutions on environmental vulnerability (Gaiha \& Thapa, 2006; Swain \& Floro, 2014). However, the impact of non-financial microfinance services impact on women-owned micro-enterprise sustainability and the moderating role of environmental disaster are not documented within one construct. Therefore, this study fills the gap by exploring the research variables in distinctive emerging economies of Pakistan and Malaysia. 


\section{Conclusion}

It is concluded that in contrasting economies context, the environmental disaster has a significant impact on the women's micro-enterprise sustainability. Moreover, the micro training has a statistically significant impact on women's micro-enterprise sustainability while insignificant impact of social capital on women's microenterprise sustainability. Interestingly, the environmental disaster has a significant moderating role between micro training and women's micro-enterprise sustainability. Micro training (microfinance institution's service) has a pivotal role in strengthening women's self-sustainability while social capital (microfinance institution's service) has no constructive role in developing the relationship between considered variables in both countries; Pakistan and Malaysia. These services facilitate the success of women's micro-enterprise that leads to increase income through enhancing their self-sustainability level. Lastly, environmental disasters have a significant influence on women's self-sustainability through micro-enterprises owned by women. Environmental disasters limit the positive contribution of microfinance institutions towards women's micro-enterprises and their selfsustainability.

The impact of environmental disaster on the women's micro-enterprise sustainability, especially the moderating role environmental disaster between micro training and women's micro-enterprise sustainability. These are major contribution towards the existing literature, as these dimensions were not explored previously. This finding signifies that an environmental disaster is the most crucial limiting problem in women-owned microenterprise sustainability in emerging economies; Pakistan and Malaysia.

Secondly, the present theoretical framework considered only non-financial services while previously the focus was limited largely to financial services. Hence, this study is unique in offering the insight about less explored dimension. Additionally, the regional context is explored by including comparative analysis, which delimits the knowledge from region-specific.

Thirdly, Mayoux's Feminist Empowerment Theory's limitations are identified by the present findings of this study. Aforementioned theory claimed that women empowerment enhances due to microfinance institutions. On the other hand, present findings proved that in hazardous areas, the microfinance institutions are unable to empower the women as supported by the Relational Theory of Risk. Therefore, Mayoux's Feminist Empowerment Theory is not the right fit in hazardous situation such as, environmental disasters. Thus, this study offers a new distinctive dimension to existing theories.

The findings serve practical implications such as the results of this study explored the weak areas requiring improvement in the women-owned and managed micro-enterprises and their sustainability. Furthermore, it leads to foster entrepreneurial practices, in order to sustain business activities in highly vulnerable low-income households in Pakistan and Malaysia. At large, the current research findings could be applied to other emerging economies to assess the women's micro-enterprise sustainability. Particularly, the policymakers can benefit from the present results by improving the areas to promote sustainability and economic stability through social capital and micro training while finding ways to improve the relocation of the women-enterprises to less environmentally vulnerable areas in Pakistan and Malaysia.

Additionally, microfinance institutions benefit from this study for attaining their ultimate objective of enhancing sustainability among women-owned enterprise. The use of social capital and micro training programme would be highly effective for improving the opportunity in creating micro-enterprises. The educating of women is vital for these institutions. Hence, they should encourage the women to participate in workshops and social networking so that their micro-enterprises attain sustainability.

The Central bank of Pakistan and Malaysia should work in close collaboration with the government in empowering womenfolk. The schemes should be designed to ensure that in times of environmental disasters, there is enough backing for these vulnerable women entrepreneurs. The use of microfinance non-financial services workshops should be made compulsory for women entrepreneurs so that they have complete awareness 
about strategic steps in such situations. Furthermore, governments should facilitate a safe area for women to run their own businesses. Additionally, government should also offer micro-enterprises the credit scheme as reliance alone on the microfinance institutions services are not sufficient. Hence, the strategic framework should be developed to reduce the environmental disaster's impact on women's micro-enterprises so that there is higher women's self-sustainability through invariable support.

\section{References}

Akanji, O. (2006) Microfinance as a Strategy for Poverty Reduction. Central Bank of Nigeria Economic and Financial Review, 39, 111-134.

Al-Shami, S.S.A., Razali, M.M., Majid, I., Rozelan, A., Rashid, N. (2016) The Effect of Microfinance on Women's Empowerment: Evidence From Malaysia. Asian Journal of Women's Studies, 22, 318-337. https://doi.org/10.1080/12259276.2016.1205378

Atmadja, A.S., Su, J.-J., Sharma, P. (2016). Examining the Impact of Microfinance on Microenterprise Performance (Implications for Women-owned Microenterprises in Indonesia). International Journal of Social Economics, 43, 962-981. https://doi.org/10.1108/IJSE08-2014-0158

Bali Swain, R., Floro, M. (2014). Microfinance, Vulnerability and Risk in Low Income Households. International review of applied economics, 28, 539-561. https://doi.org/10.1080/02692171.2014.918937

Banerjee, S.B., Jackson, L. (2017). Microfinance and the Business of Poverty Reduction: Critical Perspectives from Rural Bangladesh. Human relations 2017, 70, 63-91. https://doi.org/10.1177/0018726716640865

Baron, R.M., Kenny, D.A. (1986). The Moderator-Mediator Variable Distinction in Social Psychological Research: Conceptual, Strategic, and Statistical Considerations. Journal of personality and social psychology, 51, 1173. https://doi.org/10.1037/0022-3514.51.6.1173

Bateman, M. (2010). Why Doesn't Microfinance Work?: The Destructive Rise of Local Neoliberalism. Zed Books Ltd. ISBN-10: 1848133324

Becker, J., Kovach, A.C., Gronseth, D.L. (2004). Individual Empowerment: How Community Health Workers Operationalize Self determination, Self sufficiency, and Decision making Abilities of Low income Mothers. Journal of Community Psychology, 32, 327342. https://doi.org/10.1002/jcop.20000

Belas, J.; Gavurova, B.; Cepel, M.; Kotaskova, A. 2018. Relationship of gender to the position of Slovak University students on the socio-economic determinants of the business environment and the development of entrepreneurship, Entrepreneurship and Sustainability Issues 6(2): 968-978. https://doi.org/10.9770/jesi.2018.6.2(33)

Bernard, D.K., Kevin, L.L.T., Khin, A.A. (2016). Entrepreneurial Success through Microfinance Services among Women Entrepreneurs in Sri Lanka: A Pilot study and Overview of the Findings. International Journal of Economics and Financial Issues, 6, 1144-1150.

Birkmann, J. (2006). Measuring Vulnerability to Promote Disaster-Resilient Societies: Conceptual Frameworks and Definitions. Measuring vulnerability to natural hazards: Towards disaster resilient societies, 1, 9-54.

Blaikie, P., Cannon, T., Davis, I., Wisner, B. (2004). At Risk: Natural Hazards, People's Vulnerability and Disasters. Routledge. ISBN10: 9780415252164

Boholm, Å., Corvellec, H. (2011) A Relational Theory of Risk. Journal of Risk Research, 14, 175-190. https://doi.org/10.1080/136698 77.2010 .515313

Bosma, N.S., Levie, J. (2010). Global Entrepreneurship Monitor 2009 executive report. Retrieved from: http://www.gemconsortium. org [accessed on: 29-11-2018].

Bourdieu, P. (2003). Firing back: Against the Tyranny of the Market 2. Verso Books: 2003; Vol. 2. New York, USA: New Press, pp. 96. ISBN-10: 1859846580

Buckley, G. (1997). Microfinance in Africa: Is it Either the Problem or the Solution? World development, 25, 1081-1094. https://oi. org/10.1016/S0305-750X(97)00022-3

Burżacka, M., Gąsiorowska, E. (2016). The Importance of Venture Capital Financing of Start-Up Companies, Forum Scientiae Oeconomia, 4, 3, 141-150

Campione, W., Morgan, J., Jerrell, M. (2004). Employed Women's Well-Being: The Global and Daily Impact of Work, Working paper 
series--04-05. Retrieved from: http://openknowledge.nau.edu/id/eprint/1581 [accessed on: 29-11-2018].

Cheston, S., Kuhn, L. (2002). Empowering Women through Microfinance. Draft, Opportunity International, 64

Cohen J., Cohen P., West S.G., Aiken L.S., (2013). Applied Multiple Regression/Correlation Analysis for the Behavioural Sciences: New York: Routledge.

Dichter, T. (2007). Can Microcredit Make an Already Slippery Slope More Slippery?: Some Lessons From the Social Meaning of Debt. What's wrong with microfinance?, Practical Action Publishing in association with GSE Research: 7, 7-18. Retrieved from: http://www. cato.org/pubs/dbp/dbp1.pdf [accessed on: 29-11-2018].

Dickerson, A., Taylor, M.A. (2000). Self-limiting Behavior in Women: Self-esteem and Self-efficacy as Predictors. Group \& Organization Management, 25, 191-210. https://doi.org/10.1177/1059601100252006

Faizan, R., \& Haque, A. U. (2016). The Relationship between Societal Attributes, Feminine Leadership \& Management Style: Responses from Pakistan's Urban Region Female-Owned Businesses. European Journal of Business and Management. 8(23), $171-191$.

Gaiha, R., Thapa, G. (2006). A Methodology for Assessment of the Impact of Microfinance on Empowerment and Vulnerability. International Fund for Agricultural Development (IFAD). Retrieved from: http://www.ifad.org/operations/projects/regions/pi/paper/2. pdf [accessed on: 29-11-2018].

Garikipati, S. (2008) The impact of Lending to Women on Household Vulnerability and Women's Empowerment: Evidence from India. World Development 36, 2620-2642. https://doi.org/10.1016/j.worlddev.2007.11.008

Hair Jr, J.F., Lukas, B. (2014). Marketing research (Vol. 2). McGraw-Hill Education Australia.

Hair, J.F., Sarstedt, M., Pieper, T.M., Ringle, C.M. (2012). The Use of Partial Least Squares Structural Equation Modeling in Strategic Management Research: A Review of Past Practices and Recommendations for Future Applications. Long range planning, 45, 320-340. https://doi.org/10.1016/j.lrp.2012.09.008

Hameed, W., Mohammad, H., Shahar, H. (2018). Pursuing Goal of Self-sustainability But Leads Towards More Instability: Challenges and Way Forward of Self-help Groups (SHGs). International Journal of Business and Tehnopreneurship, 8, 67-76.

Harley, D., Grome, S., Kim, S.-H., McLendon, T., Hunn, V., Canfield, J., Rose, T., Wells, A. (2018). Perceptions of Success and SelfSustainability Among Women Participating in Entrepreneurial Skills Development and Empowerment Program Through Photovoice. Journal of Ethnic \& Cultural Diversity in Social Work, 1-19.

Henseler, J., Ringle, C.M., Sinkovics, R.R. (2009). The Use of Partial Least Squares Path Modeling in International Marketing. New Challenges to International Marketing, Emerald Group Publishing Limited: 277-319.

Hofstede.com, (2018). Comparison of Pakistan and Malaysia. Retrieved from: https://www.hofstede-insights.com/product/comparecountries/. [accessed on: 29-11-2018].

Hossain, S. (2007). Poverty and Vulnerability in Urban Bangladesh: The Case of Slum Communities in Dhaka City. International Journal of Development Issues, 6, 50-62. https://doi.org/10.1108/14468950710830554

IBRU, (2009). D.M.C. Growing Microfinance through New Technologies-. 2009.

Islam, R., Abdul-Ghani, A.B., Abidin, I.Z., and Rayaiiappan, J. M. (2017). Impact on Poverty and Income Inequality in Malaysia's Economic Growth. Problems and Perspectives in Management, 15(1), 55-62. https://doi.org/10.21511/ppm.15(1).2017.05

Kabeer, N. (2012). Women's Economic Empowerment and Inclusive Growth: Labour Markets and Enterprise Development. School of oriental and African studies, UK. Retrieved from: http://www.idrc.ca/EN/Documents/NK-WEE-Concept-Paper.pdf. [accessed on: 29-11-2018].

Kapila, M., Singla, A., Gupta, M. (2016). Impact of Microcredit on Women Empowerment in India: An Empirical Study of Punjab State, Proceedings of the World Congress on Engineering. Vol. II. London: UK.

Kithae, P.P., Nyaga, J.G., Kimani, J.G. (2013). Role of Microfinance Factors on the Sustainability of Women Managed Micro and Small Enterprises (MSEs) in Kenya. International NGO Journal, 8, 94-99. https://doi.org/10.5897/INGOJ2013.0271

Kot, S., Meyer, N., Broniszewska, A. (2016). A Cross-country Comparison of the Characteristics of Polish and South African women Entrepreneurs. Economics and Sociology, 9(4), 207-221. https://doi.org/10.14254/2071-789X.2016/9-4/13

Mafukata, M.A., Dhlandhlara, W., Kancheya, G. (2015). Socio-demographic Factors Affecting Social Capital Development, Continuity 
and Sustainability among Microfinance Adopting Households in Nyanga, Zimbabwe. Journal of Social Entrepreneurship, 6, $70-79$. https://doi.org/10.1080/19420676.2014.954257

Mahmood, S. (2011). Microfinance and Women Entrepreneurs in Pakistan, International Journal of Gender and Entrepreneurship, 3(3), 265-274. https://doi.org/10.1108/17566261111169340

Mata-Lima, H., Alvio-Borba, A., Pinheiro, A., Mata-Lima, A., Almeida, J. S. (2013). Impacts of Natural Disasters on Environmental and Socio-economic Systems: What Makes the Difference?, Ambiente \& Sociedade, 16(2). https://doi.org/10.1590/S1414$753 \mathrm{X} 2013000300004$

Mayoux, L. (1999). Questioning virtuous spirals: Micro finance and Women's Empowerment in Africa. The Journal of the Development Studies Association, 11, 957-984. https://doi.org/10.1002/(SICI)1099-1328(199911/12)11:7<957::AID-JID623>3.0.CO;2-\%23

Mayoux, L. (2005). Women's Empowerment through Sustainable Microfinance. Rethinking Best

Mayoux, L. (1998). Participatory Learning for Women's Empowerment in Micro finance Programmes: Negotiating Complexity, Conflict and Change. IDS bulletin, 29, 39-50. https://doi.org/10.1111/j.1759-5436.1998.mp29004005.x

Meyer, N. (2018). Research on Female Entrepreneurship: Are We Doing Enough? Polish Journal of Management Studies, 17(2), 158169. https://doi.org/10.17512/pjms.2018.17.2.14

McEntire, D., Gilmore Crocker MPH, C., Peters, E. (2010). Addressing Vulnerability through an Integrated Approach. International Journal of Disaster Resilience in the Built Environment, 1, 50-64. https://doi.org/10.1108/17595901011026472

Mosley, P., Hulme, D. (2009). Is There a Conflict Between Growth and Poverty Alleviation. Microfinance: A reader 2009, 65. https:// doi.org/10.1016/S0305-750X(98)00021-7

Musa, M., Shuib, R., Selamat, N. H., Mohd Isa, S., Osman, I., \& Abu Bakar, S. (2016). A Study of Women Micro Entrepreneurs in Malaysia: Livelihood Strategies and Challenges.

Naala, M.N.I. (2016). Moderating and Mediating Roles of Human Capital and Competitive Advantage on Entrepreneurial Orientation, Social Network and Performance of SMEs in Nigeria. Universiti Utara Malaysia.

Njaramba, J., Whitehouse, H., Leeross, D. (2018a). Approach towards female African migrant entrepreneurship research, Entrepreneurship and Sustainability Issues 5(4): 1043-1053. http://doi.org/10.9770/jesi.2018.5.4(24)

Njaramba, J, Chigeza, P, Whitehouse, H. (2018b). Barriers and challenges experienced by migrant African women entrepreneurs in North Queensland, Australia, Entrepreneurship and Sustainability Issues 5(4): 1054-1068. http://doi.org/10.9770/jesi.2018.5.4(25)

Nil, N.A.M., Hamid, A.H.A., Woon, C.C. (2011) Factors Affecting Profitability of Women Entrepreneurs Business in Malaysia, Annual Summit on Business and Entrepreneurial Studies (ASBES 2011) Conference Proceeding, Master Resources.

Nsengimana, S., Tengeh, R.K., Iwu, C.G. (2017). The Sustainability of Businesses in Kigali, Rwanda: An Analysis of the Barriers Faced by Women Entrepreneurs. Sustainability, 9, 1372. https://doi.org/10.3390/su9081372

Pakistan Microfinance Review Report, (2017). Annual Assessment of the Industry. Pakistan Microfinance Network. Retrieved from: http://microfinanceconnect.info/assets/articles/da6af2f0f19ca541bbc04db2f158cf98.pdf 2017, 1-92. [accessed on: 29-11-2018].

Pokhriyal, A.K., Rani, R., Uniyal, J. (2014). Role of Micro-finance in the Empowerment of the Women. Journal of Business and Finance, 2, 21-31.

Postmus, J.L., Plummer, S.-B., McMahon, S., Zurlo, K.A. (2013). Financial Literacy: Building Economic Empowerment with Survivors of Violence. Journal of Family and Economic Issues, 34, 275-284. https://doi.org/10.1007/s10834-012-9330-3

Putnam, R.D. (2000). Bowling Alone: America's Declining Social Capital. Culture and politics, Springer 223-234. https://doi. org/10.1007/978-1-349-62397-6_12

Rehman, H., Moazzam, A., Ansari, N. (2015). Role of Microfinance Institutions in Women Empowerment: A Case Study of Akhuwat, Pakistan. South Asian Studies, 30, 107.

Scott, E.K., London, A.S., Gross, G. (2007). I Try Not to Depend on Anyone but Me": Welfare reliant Women's Perspectives on Self sufficiency, Work, and Marriage. Sociological Inquiry, 77, 601-625. https://doi.org/10.1111/j.1475-682X.2007.00210.x

Ślusarczyk, B., Broniszewska, A. (2014). Entrepreneurship of Women in Poland and the EU: Quantitative Analysis. Polish Journal of Management Studies 2014, 9, 217-224. 
Sulphey, M.; Alkahtani, N.S. (2016). Economic Security and Sustainability Through Social Entrepreneurship: The Current Saudi Scenario. Journal of security and sustainability issues, 6(3), 479-489. https://doi.org/10.9770/jssi.2017.6.3(12)

Stromquist, N.P. (2015). Women's Empowerment and Education: Linking Knowledge to Transformative Action. European Journal of Education, 50, 307-324. https://doi.org/10.1111/ejed.12137

Ul-Hameed, Imran, M., Ślusarczyk, B., \& Haque, A.U. (2019). The Moderating Role of Malaysian Government in Microcredit Organization and Quality of Women Self-Sustainability, Quality-Access to Success, 20(S1), 481-486.

Wansamo, K. (2007). Towards Building Stability in a Multinational/Ethnic Society: Conflicts in Sidaamaland, Ethiopia. Lancaster University.

Yasmeen, K. (2015). The impact of microfinance loan on women's empowerment and happiness in Pakistan. Universiti Utara Malaysia. Doctoral Thesi. Retrieved from: http://etd.uum.edu.my/5749/2/s94371_02.pdf [accessed on: 29-11-2018].

Yunus, M., Jolis, A. (2003). Banker to the Poor Micro-lending and the Battle against World Poverty. Revised Edition. New York, USA: PublicAffairs. 